\title{
Meningkatkan Prestasi Perbankan Melalui Alokasi Dana Pendidikan Pada Bank PD. BPR Sarimadu Kabupaten Kampar
}

\author{
ARMAN \\ Dosen tetap Sekolah Tinggi Ilmu Ekonomi Bangkinang \\ Email: armands64@ rocket mail.com
}

\begin{abstract}
This research is motivated by the education cost allocation policy by this company, the problems that occurred allocation of education costs unstable that threaten the sustainability of educational activities for employees. Based on the theory that education affects performance, but what about the presence of unstable budget allocations for education, whether affecting employee performance at work. Quantitative research using time series data for the year 2003 to the year 2013 and analyzed using simple linear regression. Based on the research result shows that the allocation of the cost of education proved to have a significant influence on employee performance Bank PD. RB Sarimadu Kampar district (3,155> 2,228) are shown on the company's revenues continue to increase. in order to improve employee performance and in turn is raise the performance of the company, then the company needs to allocate the cost of education and the increasing cost of education and create a stable allocation of the cost of education by way of budgeting as fixed costs in the company's budget.
\end{abstract}

Keywords : Cost of Education and Job Performance

Pegawai merupakan sumber daya manusia yang tidak dapat diabaikan dalam menghasilkan hasil suatu organisasi yang perlu mendapatkan perhatian. Sebab apabila tidak diperhatikan akan berdampak pada prestasi kerja. Berbicara masalah prestasi kerja merupakan sarana untuk memperbaiki mereka yang tidak melakukan tugasnya dengan baik di dalam organisasi. Banyak organisasi yang berusaha untuk mencapai sasaran atau kedudukan yang terbaik dan terpercaya dalam bidangnya. Untuk itu sangat tergantung dari para pelaksananya, yaitu para pegawainya agar mereka mencapai sasaran yang telah ditetapkan oleh organisasi.

Penelitian ini mengambil tema masalah prestasi kerja pegawai dalam melaksanakan tugasnya di Bank PD. BPR Sarimadu Kabupaten Kampar. Bank ini adalah milik Pemerintah Daerah Kabupaten Kampar. Bank ini memiliki 1 (satu) Kantor Pusat di Bangkinang 3 (tiga) kantor Cabang yaitu cabang Ujung Batu, Cabang Lipat Kain dan Cabang Pekanbaru serta 7 (tujuh) Kantor Pelayanan Kas. Penelitian ini memfokuskan pada masalah alokasi biaya pendidikan bagi pegawai Bank PD. BPR Sarimadu Kabupaten Kampar, dimana diketahui bahwa perusahaan ini membuat kebijakan tentang mengalokasikan biaya pendidikan bagi para pegawainya dalam rangka meningkatkan kinerja mereka di masa yang akan datang.

Tertarik melakukan rencana penelitian pada Bank PD. BPR Sarimadu Kabupaten Kampar dengan alasan bahwa: bank ini merupakan bank milik pemerintah daerah dalam hal ini adalah Pemerintah Daerah Kabupaten Kampar yang mana karyawan yang bekerja merupakan putra daerah khususnya Kabupaten Kampar, kemudian diikuti dengan Bank PD. BPR Sarimadu Kabupaten Kampar telah berulang kali memberikan pelatihan kepada pegawainya dengan tujuan agar kredit yang disalurkan benar-benar mendapatkan perlakuan sebagaimana mestinya sehingga terhindar dari masalah kredit macet. Diketahui bahwa biaya pendidikan yang dialokasikan mengalami fluktuasi dari tahun ke tahun, tujuan biaya pendidikan ini jelas yakni untuk meningkatkan prestasi 
kerja para pegawai dalam rangka meningkatkan pendapatan perusahaan.

Kemudian jumlah pegawai Bank PD. BPR Sarimadu Kabupaten Kampar dilihat dari tugasnya. Selain itu juga bila dikaitkan dengan masalah masalah pegawai yang bekerja pada Bank PD. BPR Sarimadu lebih memberdayakan tenaga kerja lokal atau putra daerah Kabupaten Kampar, kemudian masalah komitmen dari pegawai dalam menjalankan bisnis perbankan mestinya tidak diragukan lagi dan bahkan Bank PD. BPR Sarimadu telah memberikan beberapa kali pelatihan dalam rangka pengembangan pegawai dalam bekerja khususnya berkaitan dengan masalah analis kredit. Bank

PD. BPR Sarimadu juga sudah berusaha dalam hal perekrutan karyawan secara profesional dengan melakukan berbagai macam tahapan seleksi dengan tujuan untuk mendapatkan calon pegawai yang memiliki kompetensi yang baik serta mampu untuk menghadapi pesaingan dengan perbankan lainnya.

Teori yang digunakan menurut Mangkunegara (2000: 67) menyebutkan prestasi kerja atau prestasi, sesungguhnya yang dicapai seseorang. Pengertian prestasi kerja adalah hasil kerja secara kualitas dan kuantitas yang dicapai oleh seseorang dalam melaksanakan tugasnya sesuai dengan tanggung jawab yang diberikan kepadanya. Hal senada juga disampaikan oleh Widodo (2001: 47) bahwa prestasi kerja atau kinerja adalah sesuatu yang dicapai, prestasi yang diperlihatkan dan kemampuan kerja. Kemudian Osbone (1980) prestasi kerja adalah suatu tingkat pencapaian misi organisasi. Menurut Prawirosentono (1999: 137), performance atau prestasi kerja adalah hasil kerja yang dapat dicapai oleh seseorang atau sekelompok orang dalam suatu organsisasi sesuai dengan wewenang dan tanggung jawab masing-masing dalam upaya mencapai tujuan organisasi secara legal, tidak melanggar hukum dan sesuai dengan moral dan etika.

Menurut Griffin dan Moorhead (1986: 217) bahwa prestasi kerja adalah suatu kumpulan total dari perilaku kerja yang ada pada pekerja. Kemudian Mitriani (1995: 109) mengemukakan bahwa prestasi kerja bila ditinjau dari segi proses adalah sebagai seperangkat proses untuk menciptakan pemahaman bersama mengenai apa yang harus dicapai. (bagaimana hal itu harus dicapai), serta bagaimana mengatur orang dengan cara yang dapat meningkatkan kemungkinan tercapainya tujuan. Kemudian Patrick (1977: 1) menjelaskan prestasi kerja sebagai perilaku yang berhubungan dengan penyelesaian pekerjaan yang diharapkan, spesifik atau bersifat formal oleh masingmasing anggota organisasi.

Kesimpulan dari pengertian prestasi kerja adalah pencapaian hasil kerja, pegawai yang memiliki prestasi kerja yang baik, akan menyebabkan prestasi kerja organisasi juga semakin baik.

Menurut Robins (2001 : 273), bahwa: "Sejumlah faktor struktural menunjukkan suatu hubungan ke prestasi kerja. Di antara faktor yang lebih menonjol adalah persepsi peran, norma, inekuitas status, ukuran kelompok, susunan demografinya, tugas kelompok dan kekohesifan (saling terkait)". Selanjutnya menurut Katz (1969) pelaksanaan tugas atau tujuan organisasi memerlukan dukungan struktur organisasi, seperti dasar hukum, tata kerja, fasilitas dan lain-lain. Kemampuan struktur organisasi merupakan kemampuan administrasi, yakni kemampuan organisasi untuk mencapai atau menyelesaikan tugas-tugas yang didukung oleh struktur organisasi di samping lingkungannya. Seberapa jauh kemampuan organisasi melaksanakan fungsi sangat tergantung pada tersedianya tenaga terlatih, resources dan tingkat kewenangan. (Katz, 1969 : 100).

Selanjutnya Wriht dkk (1996 : 188), berpendapat bahwa: "Struktur organisasi adalah sebagai bentuk cara dimana tugas dan tanggung jawab dialokasikan kepada individu, dimana individu tersebut dikelompokkan ke dalam kantor, departemen dan divisi. Struktur organisasi hendaknya selalu menyesuaikan dengan 
perkembangan kebu tuhan publik dan lingkungan hal tersebut bertujuan untuk terciptanya prestasi kerja organisasi yang efektif dan proses kerja yang cepat". Menanggapi pendapat diatas, maka dapat disimak bahwa untuk terciptanya prestasi kerja organisasi yang efektif agar tercipta suatu keadaan untuk mempercepat proses kerja yang cepat dibutuhkan struktur organisasi yang bisa memenuhi kebutuhan publik dalam era otonomi saat ini. Sedangkan menurut Mangkunegara (2002: 67) mengatakan bahwa faktor-faktor yang mempengaruhi prestasi kerja atau prestasi kerja pegawai adalah: 1) Faktor kemampuan dan 2) Faktor motivasi. Selanjutnya Thoha (1996: 27) mengemukakan bahwa prestasi kerja dipengaruhi oleh berbagai faktor yang didapat dikelompokkan menjadi dua faktor yaitu faktor individu dan faktor kepercayaan, pengalaman, penghargaan, dan sebagainya.

Kemudian faktor-faktor yang mempengaruhi prastasi kerja, secara rinci dikemukakan oleh Simanjuntak (1983: 24) yaitu terdiri dari pendidikan dan latihan, gizi dan kesehatan, penghasilan dan jaminan sosial, pemberian kesempatan, manajemen dan kebijaksanaan pemerintah untuk mengetahui seberapa jauh tingkat prestasi kerja yang dicapai maka diperlukan pengukuran. Dalam hal ini terdapat beberapa faktor yang dianggap penting bagi pelaksanaan pekerjaan seperti kualitas pekerjaan, kuantitas pekerjaan, dan sikap. Selanjutnya Gibson (1997: 183), mengemukakan bahwa setiap usaha untuk mengetahui mengapa seseorang berprilaku seperti yang dilakukan selama ini dalam organisasi memerlukan pemahaman tentang: (1) individu yang memiliki kemampuan, keterampilan mencakup mental dan fisik, latar belakang: keluarga, umur dan jenis kelamin, (2) organisasi meliputi : sumber daya, kepemimpinan, imbalan dan prosedur kerja, dan (3) psikologi meliputi: persepsi, sikap, kepribadian dan motivasi. Lebih dari itu, adapun yang mempengaruhi faktorfaktor prestasi kerja dalam suatu organisasi adalah faktor kemampuan dan faktor motivasi (Anwar Prabu, 2002: 67).
Dari Pengertian di atas, dan faktor yang mempengaruhi prestasi kerja maka dapat disimpulkan bahwa pendidikan merupakan salah satu faktor yang mempengaruhi prestasi kerja pegawai bank. Pengembangan SDM (Human Resources Development) secara makro menurut Soekidjo (1998: 1) adalah suatu proses peningkatan kualitas atau kemampuan manusia dalam rangka mencapai suatu tujuan pembangunan manusia. Proses peningkatan di sini menyangkut perencanaan, pengembangan dan pengelolaan SDM. Sedangkan secara mikro dalam arti lingkungan suatu unit kerja (departemen atau lembaga-lembaga yang lain), maka sumber daya manusia yang dimaksudkan adalah tenaga kerja, pegawai atau karyawan (employee). Pembangunan suatu bangsa memerlukan aset pokok yang disebut sumber daya (resources). Baik sumber daya alam (nature resources) maupun sumber daya manusia (human resources). Kedua sumber daya tersebut sangat penting dalam mencapai keberhasilan suatu pembangunan. Berbicara masalah sumber daya manusia tidak terlepas dari masalah kualitas dan kuantitas. Kuantitas menyangkut jumlah sumber daya manusia yang kurang penting hakikatnya dalam pembangunan dibandingkan dengan kualitas. Bahkan kuantitas sumber daya manusia tanpa disertai dengan kualitas yang baik akan menjadi beban pembangunan. Sedangkan kualitas menyangkut mutu sumber daya manusia yang menyangkut kemampuan, baik kemampuan fisik maupun kemampuan non fisik (kecerdasan dan mental). Untuk meningkatkan kualitas tersebut perlu program-program seperti progam kesehatan gizi, pendidikan dan pelatihan. (Soekidjo, 1998: 1)

Hal serupa juga disampaikan oleh Moekijat (1995: 78) bahwa pengembangan sumber daya manusia merupakan suatu cara yang efektif untuk mengatasi beberapa tantangan yang dihadapi oleh kebanyakan organisasi yang besar, tantangan ini mencakup kekunoan pegawai, perubahan sosioteknis dan perpindahan pegawai. 
Menurut Mathis (2001: 13) bahwa pekerjaan pasti berevoluasi dan berubah, pelatihan yang berkesinambungan diperlukan untuk tanggap pada perubahan teknologi.

Mangkuprawira (2003: 151) juga menyatakan pengembangan sumber daya manusia jangka panjang, sebagai perbedaan dari pelatihan untuk pekerjaan spesifik, merupakan bagian penting bagi departemen SDM. Melalui pengembangan karyawan yang ada, departemen mengurangi ketergantungan perusahaan pada penyewaan karyawan baru. Jika karyawan dikembangkan dengan baik, pekerjaan yang terbuka dan diperoleh dari perencanaan SDM sangat mungkin diisi dari dalam perusahaan sendiri. Promosi dan pengalihan posisi karyawan juga menunjukkan bahwa mereka juga memiliki peluang karir, tidak hanya berhenti pada sebuah posisi pekerjaan. Pengusaha memperoleh manfaat dari kelanjutan operasional dengan prestasi kerja yang meningkat, sementara karyawan merasa memiliki komitmen lebih besar dari perusahaan.

Menurut Davis (1996: 151) memandang pengembangan SDM merupakan sebuah cara efektif untuk menghadapi tantangan-tantangan, termasuk ketertinggalan karyawan, keragaman pekerja di dalam dan di luar negeri, perubahan teknik kegiatan yang disepakati, dan perputaran karyawan. Dalam menghadapi tantangan-tantangan tersebut, departemen SDM dapat memelihara pekerja yang efektif dengan program ini. Mangkuprawira (2003: 152) menjelaskan bahwa alasan pengembangan SDM, antara lain: 1) Ketertinggalan karyawan, ketertinggalan ini terjadi ketika seorang karyawan tidak lagi memiliki pengetahuan atau kemampuan yang dibutuhkan untuk melaksanakan pekerjaan yang penuh tantangan dengan sukses. 2) Keragaman karyawan domestik dan internasional, kecenderungan menghadapi bisnis global dan keragaman karyawan juga menjadikan tantangan tersendiri bagi departemen SDM. 3) Perubahan teknologi, perubahan teknologi yang cepat mendorong perusahaanperusahaan secara teknis melaksanakan pengembangan yang berkesinambung. 4) Perputaran karyawan, perputaran karyawan menciptakan tantangan khusus untuk mengembangkan SDM. Keluarnya karyawan dari perusahaan sebagai sesuatu yang tidak dapat diperkirakan. Oleh karenanya, kegiatan pengembangan harus dilakukan perusahaan dalam menyiapkan para karyawan untuk berhasil hidupnya manakala mereka ke luar.

Menurut Siagian (2008: 181) bahwa sumber daya manusia merupakan sumber daya terpenting yang dimiliki oleh suatu organisasi, salah satu implikasinya adalah bahwa investasi terpenting yang mungkin dilakukan oleh suatu organisasi adalah bidang sumber daya manusia. Pengembangan sumberdaya manusia menekankan pada peningkatan kemampuan melaksanakan tugas baru di masa depan. Bagi suatu organisasi paling tidak terdapat tujuh manfaat penyelenggaraan program pengembangan, antara lain: 1) Meningkatkan produktivitas kerja organisasi sebagai keseluruhan karena tidak terjadinya pemborosan, kecermatan pelaksanaan tugas, tumbuh suburnya kerjasama dan memiliki tekad bersama untuk mencapai tujuan. 2) Terwujudnya hubungan yang serasi antara atasan dengan bawahan antara lain karena adanya pendelegasian wewenang, interaksi dan sikap. 3) Terwujudnya proses pengambilan keputusan yang lebih cepat dan tepat. 4) Meningkatkan semangat kerja seluruh tenaga kerja dalam organisasi dengan komitmen organisasional yang tinggi. 5) Mendorong sikap keterbukaan manajemen dalam menerapkan gaya manajerial yang partisipatif. 6) Memperlancar jalannya komunikasi yang efektif pada gilirannya memperlancar proses perumusan kebijakan organisasi. 7) Penyelesaian konflik seara fungsional yang dampaknya adalah tumbuh suburnya rasa persatuan.

Menurut Suyanto (2007: 176) bahwa strategi pengembangan sumberdaya manusia meliputi perencanaan sumber daya manusia, perekrutan dan seleksi sumberdaya manusia, pelatihan dan 
pengembangan sumber daya manusia, penilaian prestasi kerja, kompensasi dan pemeliharaan sumber daya manusia. Menurut Nicholas (1988: 358) masalah kekacauan dalam pelayanan masyarakat berkaitan dengan administrasi kepegawaian negara yaitu apabila sudah berkaitan dengan unsur politik, hal ini pengembangan pegawai menjadi terhambat. Kemudian Heidjrachman (2000: 71) bahwa efisiensi suatu organisasi sangat tergantung pada baik buruknya pengembangan anggota organisasi itu sendiri. Di dalam perusahaan yang tujuannya mencari untung, tujuan ini dapat dicapai dengan baik kalau karyawan-karyawannya dilatih seara sempurna.

Manusia pada hakekatnya adalah mahluk sosial dimana secara naluri manusia itu ingin hidup dan berkelompok. Manifestasi dari kehidupan kelompok ini antara lain timbulnya organisasi-organisasi atau lembaga-lembaga sosial atau masyarakat. Di dalam organisasi itu tiap anggota dapat memenuhi sebahagian dari kebutuhannya antara lain menampakkan harga diri dan status sosialnya. Manusia baik sebagai mahluk hidup maupun mahluk sosial mempunyai berbagai macam kebutuhan, baik kebutuhan material kebendaan maupun kebutuhan non material. Abraham Maslow mengklasifikasikan kebutuhan manusia itu dalam berbagai tingkatan kebutuhan antara lain: kebutuhan fisiologis, pangan sandang dan papan, kemudian kebutuhan jaminan keamanan, kebutuhan sosial, kebutuhan pengakuan dan penghargaan dan kebutuhan kesempatan mengembangkan diri. (Soekidjo, 1998: 3-4)

\section{METODE}

Jenis penelitian yang digunakan adalah penelitian kuantitatif, Dalam penelitian ini penulis menggunakan jenis data sekuder yakni data yang diproleh dari pihak kedua berupa dokumen dan data tersebut telah diolah. Teknik pengumpulan data yang digunakan adalah dokumentasi yakni cara pengumpulan data dengan mendapatkan langsung dari lokasi penelitian dan wawancara. Guna untuk menjawab permasalahan dan pertanyaan penelitian, maka alat analisis data yang digunakan adalah statistik inferensi.

\section{HASIL}

\section{Alokasi Biaya Pendidikan pada Bank PD. BPR Sarimadu}

Alokasi biaya pendidikan menjadi suatu kebijakan perusahaan dalam rangka meningkatkan prestasi bagi karyawan dan juga posisi akhirnya adalah untuk meningkatkan pendapatan daripada perusahaan. Kebijakan pendidikan ini diarahkan kepada peningkatkan pengetahuan, pemahaman dan kemampuan pegawai dalam rangka meningkatkan kualitas dan kuantitas pekerjaan. Perusahaan telah mengalokasikan biaya ini dan merupakan bagian penting bagi perusahaan untuk meningkatkan hasil yang dicapai dari putra putri terbaik Kabupaten Kampar dalam rangka berprestasi, hal ini agar mereka dapat bersaing dengan pesaing mereka dari tempat atau daerah lainnya. Selama beberapa tahuan terakhir yakni semenjak tahun 2003 hingga tahun 2013 ini perusahaan telah mengalokasikan biaya pendidikan yang cukup besar dan merupakan bentuk upaya perusahaan yang nyata dan alokasi ini sudah didistribusikan untuk kemajuan pegawai dalam bekerja. Berikut ini dipaparkan data tentang alokasi biaya pendidikan bagi pegawai pada Bank PD. Alokasi dana pendidikan yang diberikan perusahaan dalam rangka meningkatkan pengetahuan dan pemahaman serta kemampuan terus dialokasikan namun cenderung kurang stabil. Hal ini ditunjukkan dari data penurunan pada tahun 2013.

\section{Prestasi Kerja Karyawan Bank PD. BPR Sarimadu}

Prestasi kerja pegawai bank PD. BPR Sarimadu dapat diukur dari perkembangan pendapatan perusahaan dari beberapa tahun terakhir, pendapatan ini bersumber dari penyaluran kredit dan 
sumber lainnya. Berikut ini data perkembangan pendapatan perusahaan. Bahwa perkembangan pendapatan terus mengalami peningkatan yang mengarahkan kepada bagaimana perusahaan mendapatkannya.

\section{Pengaruh Alokasi Biaya Pendidikan Terhadap Prestasi Kerja Pegawai Bank PD. BPR Sarimadu}

Berdasarkan permasalahan diajukan bahwa alokasi biaya pendidikan memberikan pengaruh yang signifikan terhadap prestasi kerja yang dilihat dari pendapatan perusahaan. Dalam penelitian ini juga ditetapkan hipotesis yang mengatakan bahwa alokasi biaya pendidikan berpengaruh signifikan terhadap prestasi kerja pegawai pada Bank PD. BPR Sarimadu Kabupaten Kampar. Pembuktian hipotesis ini dapat dibuktikan dengan menganalisis dengan menggunakan persamaan regresi linier sederhana dan dibantu oleh program SPSS versi 16. Untuk menganalisis pengaruh alokasi biaya pendidikan terhadap prestasi kerja dibutuhkan data masing-masing variabel. Dari data tersebut dapat dijelaskan bahwa pendapatan dan alokasi biaya pendidikan sudah dialokasikan dan mengalami perkembangan pada Bank PD. BPR Sarimadu Kabupaten Kampar.

Berdasarkan hasil analisis dengan menggunakan program SPSS, maka dapat disajikan pada tabel berikut ini.

Tabel 1: Output Regresi Pengaruh Alokasi Biaya Pendidikan terhadap Prestasi Kerja Pegawai

\begin{tabular}{|c|c|c|c|c|c|}
\hline \multirow[b]{2}{*}{ Model } & \multicolumn{2}{|c|}{$\begin{array}{l}\text { Unstandardized } \\
\text { Coefficients }\end{array}$} & \multirow{2}{*}{$\begin{array}{c}\begin{array}{c}\text { Standardized } \\
\text { Coefficients }\end{array} \\
\text { Beta }\end{array}$} & \multirow[b]{2}{*}{$\mathrm{t}$} & \multirow[b]{2}{*}{ Sig. } \\
\hline & B & Std. Error & & & \\
\hline 1 (Constant) & 7.035E6 & $6.856 \mathrm{E} 6$ & & 1.026 & .332 \\
\hline $\begin{array}{l}\text { Biaya } \\
\text { Pendidikan }\end{array}$ & 44.318 & 14.045 & .725 & 3.155 & .012 \\
\hline
\end{tabular}

Sumber: Data Olahan, 2014

Berdasarkan hasil di atas maka diketahui bahwa persamaan linier sederhana dalam analisis ini adalah sebagai berikut:

$$
\mathrm{Y}=7,035+44,318 \mathrm{X}+\mathrm{e}
$$

Keterangan :

$$
\begin{array}{ll}
\mathrm{Y} & =\text { Prestasi Kerja (Pendapatan) } \\
\mathrm{X} & =\text { Biaya Pendidikan } \\
\mathrm{a} & =\text { Konstanta } \\
\mathrm{b} & =\text { Koefisien Regresi } \\
\mathrm{e} & =\text { Error (kesalahan penganggu) } \\
& \text { Arti persamaan regresi linier } \\
& \text { tersebut, yaitu: }
\end{array}
$$

Nilai a $=7,035$ menunjukkan bahwa apabila nilai alokasi biaya pendidikan sama dengan nol maka pendapatan sebesar 7,035 juta rupaih.

Nilai $\mathrm{b}=44,318$ menunjukkan bahwa setiap penambahan satu satuan variabel alokasi biaya pendidikan, maka akan meningkatkan pendapatan perusahaa sebesar 44,318 satuan variabel pendapatan.

\section{Uji t (t-test)}

Berdasarkan hasil perhitungan diperoleh nilai $t_{\text {hitung }} X$ sebesar 3,155 dan nilai $t_{\text {tabel }}$ adalah 2,228. Jadi $t_{\text {hitung lebih }}$ besar dari $t_{\text {tabel }}(3.155>2,228)$. Ini berarti pada level of signifikan sebesar 95\% Ho ditolak. Dengan demikian dapat disimpulkan bahwa alokasi biaya pendidikan memberikan pengaruh yang signifikan terhadap preastasi kerja pegawai yang dapat ditunjukkan dari pendapatan yang diperoleh Bank PD. BPR Sarimadu Kabupaten Kampar.

\section{PEMBAHASAN}

Berdasarkan hasil penelitian yang dibuktikan dengan uji hipotesis bahwa alokasi biaya pendidikan pada perusahaan dalam hal ini adalah Bank PD. BPR Sarimadu Kabupaten Kampar memberikan pengaruh yang signifikan terhadap preastasi kerja pegawai yang ditandai dengan pendapatan perusahaan yang terus mengalami peningkatan. Pendidikan menjadi salah satu usaha peningkatkan kualitas SDM dalam bekerja dan dalam hal ini perusahaan memiliki komitmen yang cukup besar dalam rangka meningkatkan dan mengembangkan SDM guna meningkatkan kualitas produk yang 
dihasilkan. Kemudian dengan peningkatan pendidikan karyawan tersebut maka akan menjadikan barometer keberhasilan perusahaan meningkatkan kinerjanya.

Hasil penelitian ini pada dasarnya mendukung hasil penelitian sebelumnya yakni Suryoadi, Yerri and Ratnawati, Intan (2012) pengaruh pelatihan dan kepuasan kompensasi terhadap kinerja karyawan pada pt. Bank muamalat indonesia cabang semarang. Undergraduate thesis, Fakultas Ekonomika dan Bisnis. Bahwa Kehadiran produk baru yang dikeluarkan oleh Bank Muamalat Indonesia adalah Shadr (Syariah Deposit Arrangement) yang mengakibatkan karyawan yang memiliki masalah karena tidak mampu beradaptasi dengan sistem baru, sehingga berdampak pada karyawan kinerja terdegradasi oleh $6,52 \%$ pada tahun 2010, dari 13,04 pada tahun 2009. Dari yhe beberapa faktor mempengaruhi kinerja karyawan cabang Bank Muamalat Indonesia Semarang adalah: (1) kegiatan pelatihan karyawan, dan (2) kepuasan kompensasi tujuan penelitian ini adalah untuk menganalisis pengaruh kegiatan pelatihan karyawan dan kepuasan kompensasi terhadap kinerja karyawan Bank Muamalat Indonesia Cabang Semarang. Sampel dari penelitian ini adalah staf dari Bank Muamalat Indonesia Cabang Semarang yang berjumlah 46 orang, yang terdiri dari 45 orang staf dan orang yang dipimpin. Data yang dikumpulkan dengan menyebarkan kuesioner kepada responden dan kemudian data dianalisis menggunakan uji reliabilitas dan validitas regresi linier berganda. Hasil penelitian menunjukkan ada pengaruh positif dan signifikan dari pelatihan di kinerja karyawan di kantor Bank Muamalat Indonesia Semarang cabang dengan nilai probabilitas 0,001. Dan ada yang positif dan signifikan kepuasan kompensasi dari thr kinerja karyawan di kantor Bank Cabang Muamalat Indonesia Semarang dengan nilai probabilitas 0,012 .

\section{SIMPULAN}

Berdasarkan hasil penelitian seperti yang telah diuraikan pada bab $\mathrm{V}$ di atas, maka dapat ditarik kesimpulan bahwa terbukti alokasi biaya pendidikan memberikan pengaruh yang signifikan terhadap prestasi kerja karyawan Bank PD. BPR Sarimadu Kabupaten Kampar yang ditunjukkan dari pendapatan perusahaan yang terus mengalami peningkatan. Dari kesimpulan di atas, maka dapat diberikan saran dalam rangka meningkatkan prestasi kerja karyawan dan pada giliranya adalah meningkatka kinerja perusahaan, maka perusahaan perlu mengalokasikan biaya pendidikan dan meningkatkan biaya pendidikan dan membuat alokasi biaya pendidikan stabil dengan cara menganggarkan sebagai biaya tetap dalam anggaran perusahaan.

\section{DAFTAR RUJUKAN}

Allen, 1990, Management and Organization, McGraw-Hill Book Kogakusha Ltd., Tokyo.

Mangkunegara, A.A. Anwar Prabu, 2002, Manajemen Sumber Daya Manusia Perusahaan, PT. Remaja Rosda Karya, Bandung

As'ad, Mohd, (1995), Psikologis Industri, Liberty, Yogyakarta

Bernadin dan Russel, 1993, Human Resources Management (An Experiential Approach, The McGraw-Hill Campanies Inc., Singapore

Bernadin dan Russel, 2000, Human Resourches Management, New York: MC, Graw Hill, Inc.

Buchanan, 1975, Penerapan Manajemen Personalia, Jakarta, Erlangga

Budiono, 2005, Kamus Ilmiah Populer Internasional, Surabaya: Alumni

Callahan dan Holzen, 1998, Government at Work: Best Practices and Model 
Program, Sage Publiesations International Education and Professional Pubhliser, London

Cascio, Wayne F., 1992, Managing Human Resources, Fourth Edition

Davis, 1996, Personal and Human Resourche Management, Mc Graw Hill, Cambridge

Dessler, Gary, 1999, Manajemen Sumber Daya Manusia, Alih Bahasa Benyamin Molan, Penyunting Triana Iskandarsyah, Jilid 2, Jakarta : Prenhallindo

Dharma, 1991, Manajemen Prestasi Kerja, Rajawali, Jakarta

Dwiyanto, Agus, 1995, Penilaian Kinerja Organiasi Publik, Yogyakarta : UGM

Dwiyanto, Agus, Kusumasari.2001, Kinerja Pelayanan Publik, Policy Brief Center for Population and Policy Studies, Yogyakarta :UGM

Edwin, 1997, Esensi Kepemimpinan, Jakarta Rineka Cipta

Gibson, 1997, Organisasi Perilaku, Struktur dan Proses, Alih Bahasa Nunuk Adiarni, Edisi 8, Jilid II, Binapura, Aksara, Jakarta

Griffin dan Moorhead, 1986, Job Satisfaction Da Organizinonal Commitment, John Witley: New York.

Heidjrachman, 2000, Heidjrachman, 2000, Manajemen Personalia, BPFE, Yogyakarta

Ivancevich dan Donnely, 1993, Organisasi, Perilaku, Struktur dan Proses, Erlangga, Jakarta
Jackson dkk, 1978, Organizational Theory, A Macro Perspektive for Management, Prentise-Hall, USA

Katz, 1969, The Sosial Psychology of Organizations, dalam Becker \& Neuhauser The Efficient Organizations, Elsevier, New York

Keban, Jeremias. T. 1995, Indikator Kinerja Pemerintah Daerah: Pendekatan Manajemen dan Kebijakan, Makalah, Seminar Sehari, Fisipol UGM, Yogyakarta

Kertonegoro, 1994, Manajemen Sumber Daya Manusia Perusahaan, Rosda: Bandung

Kumorotomo, 1996, Meningkatkan Kinerja BUMN: Antisipasi Terhadap Kompetensi dan Deregulasi, Yogyakarta: JKAP No1

Lenvine, Harold J. 1990, Psikologi Manajemen, Jakarta : Erlangga

Leon Manginson, Newstorm and Sturbuck, ed, 1981, Hand Book of Organization Design, Oxford: University Press

Lester and Newstorm, 1996, Hand Book of Organization Design, Oxford: University Press

Mangkunegara, A. A. Anwar Prabu. 2000, Manajemen Sumber Daya Manusia Perusahaan., Bandung : PT. Remaja Rosdakarya.

Mangkunegara, A.A. Anwar Prabu, 2002, Manajemen Sumber Daya Manusia Perusahaan, PT. Remaja Rosda Karya, Bandung 
Mangkuprawira, 2003, Manajemen Sumber Daya Manusia Strategik, Ghalia Indonesia, Jakarta

Mathis, 2001, Manajemen Sumber Daya Manusia, Salemba Empat, Jakarta

Mayer dan Allen, 1984, Management and Organization, McGraw-Hill Book Kogakusha Ltd., Tokyo

Mc Mann dan Nanny, 1994, Organizational Theory, A Macro Perspective for Management, USA: Prentise-Hall

Mitrani A., 1995, Manajemen Sumber Daya Manusia Berdasarkan Kompetensi, Jakarta : Pustaka Utama Grafiti

Moekijat, 1995, Manajemen Personalia dan Sumberdaya Manusia, Mandar Maju, Bandung

Mustopadijadja, 2000, Mewujudkan Good Governance dan Otonomi Daerah, Majalah Sinergi, STIA LAN

Nazir, 1988, Metode Penelitian, Penerbit Ghalia Indonesia, Jakarta

Newstrom dan Davis, 1962, Organizational Behavior, New York: Mcbraw-Hill Companies

Newstrom dan Davis, 1986, Organization Behaviour, Human Behaviour at Work, New York: McGraww-Hill

Nicholas Henry, 1988, Administrasi Negara Dan Masalah-Masalah Kenegaraan, Rajawali Press, Jakarta

Osbone, 1980, Mewirausahakan Birokrasi (Reinventing Government) : Mentransforrnasi Semangat Wirausaha ke dalam Sektor Publik, Pustaka Binaman Pressindo, Jakarta
Prawirosentono, 1999, Prawirosentono, 1999, Kebijakan Kinerja Karyawan, Cetakan Pertama, BPFE Yogyakarta, Yogyakarta

Robins, 2001, Management, Prentice Hall Inc., New Jersey

Rue \& Byars, 1981, Management Theory and Aplication, Richard D Irwin., Inc, Homewood

Salim dan Woodward, 1992, Perencanaan Pembangunan dan Pemerataan, Jakarta: LPFE-UI

Siagian, 2008, Manajemen Sumber Daya Manusia, Bumi Aksara, Jakarta

Sianipar dan Entang, 2001, Efektivitas Implementasi Kebijakan Otonomi Daerah, Depok : CV. Citra Utama

Simamora, 1995, Manajemen Sumber Daya Manusia, STIE-YKPN:

Yogyakarta

Simanjuntak, P, 1983, Produktivitas Kerja: Pengertian, Ruang Lingkupnya, Prisma Jaya:Jakarta

Soeprihanto, 2000, Mencari Bentuk Otonomi Daerah dan Upaya Memacu Pembangunan Regional di Masa Depan, Gramedia Pustaka Utama, Jakarta.

Steers, 1985, Efektivitas Organisasi, Terjemahan Magdalena Yamin Penerbit Erlangga, Jakarta

Steers, 1991, Efektivitas Organisasi, Jakarta Erlangga

Suyanto, 2007, Strategic Management Global Most Admired Companies, Andi, Yogyakarta 
72 Meningkatkan Prestasi Perbankan Melalui Alokasi Dana Pendidikan Pada Bank PD. BPR Sarimadu Kabupaten Kampar (Arman)

Thoha, 1996, Pembinaan Organisasi, Arga Kencana Abadi, Jakarta

Suryoadi, Yerri and Ratnawati, Intan (2012) pengaruh pelatihan dan kepuasan kompensasi terhadap kinerja karyawan pada PT. Bank muamalat indonesia cabang semarang. Undergraduate thesis, Fakultas Ekonomika dan Bisnis. 